\title{
两种短命植物春萌秋萌个体生态生物学特征比较
}

\author{
张 涛 $^{12}$ 孙 羽 ${ }^{3}$ 田长彦 ${ }^{1 *}$ 冯 固 $^{3}$ \\ (1 中国科学院新疆生态与地理研究所, 乌鲁木齐 830011) (2 中国科学院研究生院 北京 100049) \\ (3中国农业大学资源与环境学院 北京 100094)
}

摘 要 短命植物是新疆北部荒漠生态系统中重要组成部分, 对稳定该区沙漠生态系统、丰富物种多样性具有重 要的意义。以往对短命植物的研究多集中在春季萌发的短命植物, 秋季萌发的短命植物研究很少, 对秋季萌发短 命植物和春季萌发短命植物的生态生物学特征的异同以及它们对稳定荒漠生态系统的意义缺乏了解。选择小车 前 (Plantago minuta) 和尖喙口牛儿苗 (Erodium oxyrrhynchum) 为研究对象, 采用野外定点标记观测和室内分析结合的 方法, 研究了两种短命植物春季萌发和秋季萌发两种表现型在冠幅、生物量、物候期、菌根侵染率等生态生物学特 征方面的差异性。结果表明 秋季萌发的小车前和尖喙 $\square$ 牛儿苗能够在覆雪下越冬, 其单株的冠幅、叶片数量、干 重等均远远大于同一时期生长的春季萌发的小车前和尖喙 $\square$ 牛儿苗, 尤其是单株结种数量更是比春季萌发小车前 和尖喙 $\square$ 牛儿苗的高 13.0 和 4.4 倍 秋季萌发的小车前和尖喙 $\square$ 牛儿苗的花期分别比春季萌发小车前和尖喙 $\square$ 牛 儿苗早 14 和 $7 \mathrm{~d}$ 植株黄枯期和成熟期分别提早 3 和 $4 \mathrm{~d}$ 此外 秋季萌发小车前和尖喙 $\square$ 牛儿苗各时期的菌根侵染 率也显著高于同期春季萌发小车前和尖喙 $\square$ 牛儿苗。本研究得到以下结论 秋季萌发的小车前和尖喙 $\square$ 牛儿苗在 稳定和扩大其后代种群繁衍能力、提高防风固沙能力、稳定荒漠生态系统等方面具有重要意义。

关键词 春萌短命植物 秋萌短命植物 生态生物学特性 丛枝菌根

\section{ECOLOGICAL AND BIOLOGICAL DIFFERENCES BETWEEN SPRING AND AU- TUMN PLANTS OF TWO DESERT EPHEMERALS}

\author{
ZHANG Tao ${ }^{12}$, SUN Yu ${ }^{3}$, TIAN Chang-Yan ${ }^{1 *}$, and FENG Gu ${ }^{3}$ \\ ${ }^{1}$ Xinjiang Institute of Ecology and Geography , Chinese Academy of Sciences, Urumqi 830011, China , ${ }^{2}$ Graduate University of Chinese Academe of \\ Sciences , Beijing 100049 , China , and ${ }^{3}$ National Resources and Environment College , China Agricultural University , Beijing 100094 , China
}

\begin{abstract}
Aims Ephemerals are important in desert ecosystems, playing a key role in ecosystem stabilization. Previous research has concentrated on spring ephemerals. Little is known about biological and ecological characteristics of ephemerals that germinate in spring and autumn and about the significance of autumn ephemerals in stabilizing desert ecosystems.
\end{abstract}

Methods We marked plants of Plantago minuta and Erodium oxyrrhynchum, species that germinate in spring and autumn. We investigated their crowns, leaves and phenological characteristics in the field during their growing seasons and measured their dry weights and mean arbuscular mycorrhizal colonization rates in the laboratory.

Important findings Leaves, flowers, fruits, seeds and dry weights of autumn plants are larger than those of spring plants. For example, in autumn $P$. minuta and E. oxyrrhynchum produced 13.0 and 4.4 times as many seeds and flowered 14 and 7 days earlier, respectively, than spring plants. In addition, mean arbuscular mycorrhizal colonization rates were higher in autumn than spring plants , accelerating the absorption of phosphorus. Autumn plants had greater capability of reproduction and ecosystem stabilization, allowing them to play an important role in stabilizing the desert ecosystem.

Key words spring ephemeral plant, autumn ephemeral plant, ecological and biological characteristics , arbuscular mycorrhizae

短命植物 (Ephemerals) 是一类生长发育周期短 暂, 能够利用冬季冰雪融水和早春降雨, 在干旱炎热
的夏季到来之前迅速完成生活史的草本植物 (毛祖 美和张佃民，1994；张立运，2002a，2002b)。短命 
植物在我国主要集中分布在新疆北部的天山北麓、 准噶尔盆地、塔城盆地和伊犁谷地 (毛祖美和张佃 民，1994）。每年春季 3 月下旬开始大量短命植物 萌动破土 到 5 月有些地方短命植物盖度可以达到 $50 \%$ 以上, 能够有效地阻止地表风沙流动, 是春季新 疆北部地区沙漠稳定沙面的主要贡献者和沙漠受干 扰破坏后植被入侵的先锋植物(王雪芹等，2003)， 多数短命植物是优良的牧草。

国外对短命植物研究较早, 研究内容涉及光 照、水分、养分对短命植物生长和种群繁衍的影响 (Margaret \& Gilles，2000)、环境因素及存活策略对一 年生荒漠植物种群演替的影响 (Gutterman，2000)、资 源变化和种群大小的变化 (Breitmeyer \& Martow， 1998) 以及土地利用方式改变对地下水及短命植物 分布的影响 (Briget et al. ,2005)。国内对短命植物 也进行了大量的研究, 研究内容涉及短命植物的生 态生物学特性 (潘伟斌和黄培 $\square, 1995$ )、种子萌发 特性 (吴玲等, 2005) 、生殖繁育特性 (吕玲和谭敦 炎, 2005 ; 姚红和谭敦炎，2005a，2005b)、生态适应 性 ${ }^{1}$ ，短命植物与其共生体 AM 真菌之间的关系 (Shi et al . 2006a，2006b)、分布及其对稳定沙面的作用 (王雪芹等，2003) 等内容。

不同的植物具有不同的环境适应方式，同一种 植物的不同基因型或者表现型也有不同的适应方 式,有的短命植物春季萌发当年完成生活史, 有的则 秋季萌发并越冬到第二年夏季完成生活史。已往研 究多集中于春季萌发的短命植物, 将春季萌发和秋 季萌发短命植物结合起来研究只见于姚红和谭敦炎 (2005a，2005b) 对胡卢巴属 (Trigonella) 繁殖能力的 报道，迄今关于秋季萌发和春季萌发短命植物生态 生物学特征差异的了解十分有限。小车前 (Plantago minuta) 和尖喙 $\square$ 牛儿苗 (Erodium oxyrrhynchum) 是 古尔班通古特沙漠地区常见的优势植物, 数量多、盖 度大 5 月在一些沙丘中下部尖喙 $\square$ 牛儿苗盖度可 达 20\% 30\%, 防风固沙作用突出(王雪芹等, 2003 ）此外，二者还是牛羊喜食的牧草，具有重要的 生态生物学意义。我们最近几年连续观测发现这两 种短命植物既能在春季萌发也能在秋季萌发, 但是 对于秋季萌发的小车前和尖喙 $\square$ 牛儿苗萌发后的越 冬能力以及越冬后的生长状况并不清楚, 特别是关 于秋季萌发与春季萌发的不同表现型之间的生态生
物学差异未见有报道。本文选取春季萌发和秋季萌 发的小车前和尖咟 $\square$ 牛儿苗为研究对象, 拟通过比 较它们在生长发育状况、物候特征及防风固沙能力 等方面的异同，揭示春季萌发和秋季萌发短命植物 种群繁衍机制及其在稳定荒漠生态系统方面的重要 意义，加深对短命植物的认识和了解。

\section{1 材料和方法}

\section{1 试验材料}

试验选择小车前和尖喙 $\square$ 牛儿苗为研究材料, 二者都是一年生或多年生草本植物，生长周期短 60 $\mathrm{d}$ 左右，一般 3 月底到 4 月上旬萌发, 5 月底或 6 月 初即完成生长发育, 以种子形态进行夏季休眠躲避 干旱(张立运，2002a，2002b)。小车前和尖嚎 $\square$ 牛 儿苗种子萌发受温度和降水影响显著, 高温抑制种 子的萌发(潘伟斌和黄培 $\square, 1995$ ), 充足的降水有 利于其种子萌发 秋季遇到降水加上温度适宜，小车 前和尖喙 $\square$ 牛儿苗种子可以萌发, 但是由于该区秋 季降水分布不均且少于春季降水，所以秋季萌发的 小车前和尖喙 $\square$ 牛儿苗数量少于春季萌发的数量 ; 此外前人研究发现夏季如遇大量降水, 尖嚎 $\square$ 牛儿 苗有夏季萌发现象（Wang et al. ，2006），但是根据我 们 2005 2 2006 年连续两年观测发现夏季萌发尖潒 $\square$ 牛儿苗数量较少且大多不能完成生活史, 远不如 秋季和春季萌发的小车前和尖喙 $\square$ 牛儿苗对荒漠生 态系统贡献大。

\section{2 研究区概况}

试验地点位于雅玛里克山山前地带和古尔班通 古特沙漠三号点附近，雅玛里克山土壤为砾质棕钙 土 $\mathrm{pH}$ 值为 8.60 ,速效磷为 $5.71 \mathrm{mg} \mathrm{kg}$, 速效钾为 $178 \mathrm{mg} \mathrm{kg}$, 有机质为 $0.16 \%$;该区年均温为 6.97 ${ }^{\circ} \mathrm{C}$ 极端最低温为 $-30{ }^{\circ} \mathrm{C}$, 年平均降水量为 266.9 $\mathrm{mm}$ (叶卫英等, 2005)。古尔班通古特沙漠三号点 附近土壤为风沙土, $\mathrm{pH}$ 值为 7.87 , 速效磷为 1.65 $\mathrm{mg} \mathrm{kg}$, 有机质为 $0.18 \%$, 该区年平均气温 $6.70{ }^{\circ} \mathrm{C}$, 极端最低温低于 $-40{ }^{\circ} \mathrm{C}$, 年平均降水量为 $70 \sim 150$ mm( Wang et al . 2006)。

\section{3 试验方法}

2005 年 9 月 30 日在雅玛里克山山脚处选择长 势均匀一致的秋季萌发小车前 100 株并对其进行标 记, 2006 年 4 月 25 日在上述地点选择长势均匀一致 
的春季萌发小车前 100 株对其进行标记;2005 年 11 月 2 日在古尔班通古特沙漠三号点对选择秋季萌发 尖喙 $\square$ 牛儿苗标记, 春季萌发尖喙 $\square$ 牛儿苗标记工 作在 2006 年 4 月 6 日进行 (标记方法同上)。标记 工作结束后定期对两种植物生长发育状况和物候状 况进行观测，物候观测参照中国物候观测方法(宛敏 渭和刘秀珍，1979）,苗期每周观测一次, 进入花期 每 $3 \mathrm{~d}$ 观测一次。观测过程中测量植株的冠幅、株 高, 记录植株叶片数量及开花结果数量, 并将标记植 株连同根系完整取回室内分析, 分析其植株干重的 变化情况, 植物干重测量采用烘干法, 植株根系菌根 侵染状况用 Biemann 和 Linderman(1981) 描述的方法 进行测定，侵染率计算用 Trouvelot 等 (1986) 描述的 方法进行。

\section{4 数据处理及分析}

采用 Excel 和 SPSS 11.5 软件包对所得数据进 行分析, 采取单因素方差分析 (One-way ANOVA) 和 最小显著差异法 $(L S D)$, 分析春季萌发和秋季萌发 的小车前以及尖喙 $\square$ 牛儿苗叶片数量、单株种子数 量、干重和冠幅等生态生物学特征之间的差异。

\section{2 结果与分析}

\section{1 植株生物量变化情况及差异}

秋季萌发小车前和尖喙口牛儿苗植株叶片数量 远远大于春季萌发小车前和尖喙 $\square$ 牛儿苗 (图 1), 秋季萌发小车前叶片数一般 15 片左右, 多的可达 20 片以上, 春季萌发小车前叶片数一般 $5 、 6$ 片, 多者可 达 7、8 片 数量远远少于秋季萌发小车前; 秋季萌发 的尖喙 $\square$ 牛儿苗在各个时期叶片数量也比春季萌发 的尖喙 $\square$ 牛儿苗多。

从图 2 中可以看出, 秋季萌发的小车前和尖唤 $\square$ 牛儿苗的干物质量均远大于同时期春季萌发小车 前和尖喙 $\square$ 牛儿苗的干物质量, 秋季萌发小车前和 尖喙 $\square$ 牛儿苗的干物质量分别是同时期春季萌发的 小车前和尖喙 $\square$ 牛儿苗的 $6 \sim 8$ 和 $2 \sim 5$ 倍。此外， 秋季萌发小车前和尖喙 $\square$ 牛儿苗在 5 月上中旬干物 质积累增加速度较快, 平均分别为 $0.06 \mathrm{~g} \mathrm{~d}^{-1}$; 春季 萌发小车前和尖喙 $\square$ 牛儿苗干物质积累速度相对比 较平缓 增加幅度也不如秋季萌发小车前和尖喙 $\square$ 牛儿苗大 平均分别为 $0.01 \mathrm{~g} \mathrm{~d}^{-1}$ 。

秋季萌发小车前和尖嚎 $\square$ 牛儿苗的果实、种子 数量均明显大于春季萌发小车前和尖喙 $\square$ 牛儿苗 (表 1)。秋季萌发小车前单株果穗数多达 12 个, 是 春季萌发小车前的 4 倍; 秋季萌发小车前单株结种
数为 270 粒, 是春季萌发小车前种子数的 11 倍。秋 季萌发的尖喙 $\square$ 牛儿苗单株果实数为 97 个, 是春季 萌发尖嚎 $\square$ 牛儿苗的 12 倍 秋季萌发尖喙 $\square$ 牛儿苗 种子数量多达 485 , 是春季萌发尖喙 $\square$ 牛儿苗种子 数的 5 倍多。此外, 秋季萌发的小车前单株结实率 也明显高于与春季萌发的小车前, 是春季萌发小车 前的 3.8 倍。
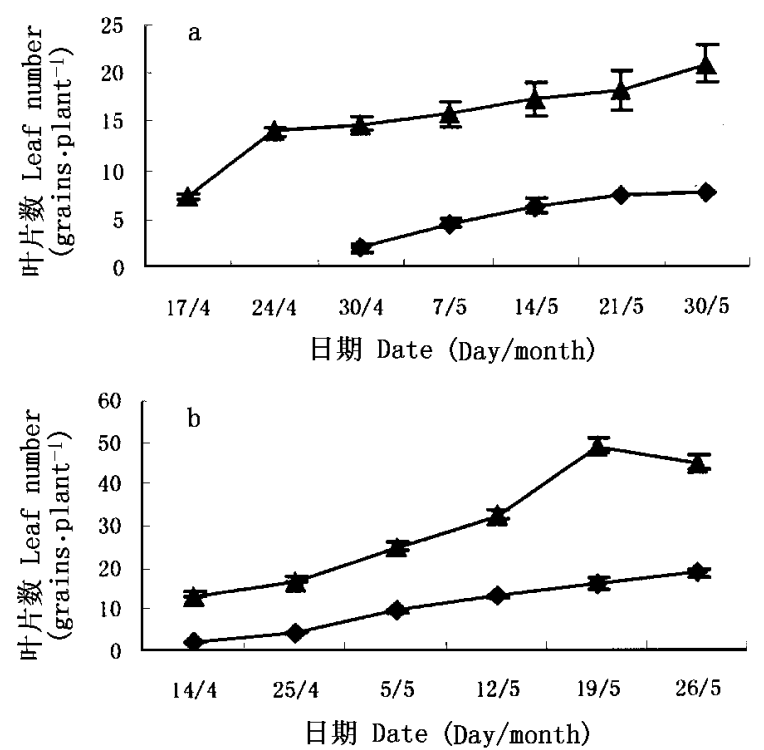

图 1 春季和秋季萌发的小车前 (a) 和尖喙口牛儿苗 (b) 叶位动态 Fig.1 The dynamic of leave number of Plantago minuta (a) and Erodium oxyrrhynchum (b) germinated in spring and autumn

三角形代表秋季萌发的植株, 菱形代表春季萌发的植株 Triangle represents autumn germinating type and diamond represents spring germinating type

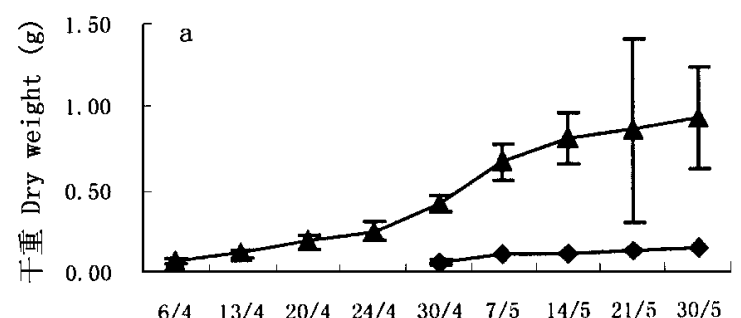

日期 Date (Day/month)

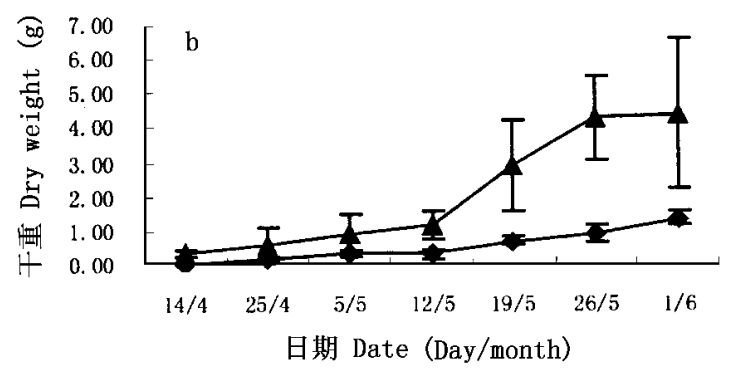

图 2 春季和秋季萌发的小车前 (a) 和尖喙 $\square$ 牛儿苗 (b)干重变化情况 Fig. 2 Dynamics of dry weight of Plantago minuta (a) and Erodium oxyrrhynchum (b) germinated in spring and autumn 图注见图 1 Notes see Fig. 1 


\section{2 植株物候变化情况及差异}

物候期的提前或延迟对短命植物躲避干旱、顺 利完成生活史具有重要的意义。观测发现不同季节 萌发的小车前或尖喙 $\square$ 牛儿苗在物候期上存在差 异 秋季萌发的小车前和尖喙 $\square$ 牛儿苗的蕾期和花
期均明显早于春季萌发小车前和尖喙 $\square$ 牛儿苗 (表 2)。秋季萌发的小车前蕾期和花期比春季萌发小车 前早两周左右 秋季萌发的尖喙 $\square$ 牛儿苗蕾期和花 期也比春季萌发尖喙 $\square$ 牛儿苗早 5 6 d。

\section{3 丛枝菌根真菌侵染状况}

表 1 春季萌发的和秋季萌发的小车前和尖喙 $\square$ 牛儿苗的单株果实、种子数和单果种子数

Table 1 Fruits number, seeds number, seed number per fruit of the two ephemerals germinated in different seasons

\begin{tabular}{lccc}
\hline \multicolumn{1}{c}{$\begin{array}{c}\text { 植物表现型 } \\
\text { Phenotypes }\end{array}$} & $\begin{array}{c}\text { 果实数 } \\
\text { Fruit number }\end{array}$ & $\begin{array}{c}\text { 种子数 } \\
\text { Seed number }\end{array}$ & $\begin{array}{c}\text { 单果种子数 } \\
\text { Seed number per fruit }\end{array}$ \\
\hline 春季萌发小车前 Plantago minuta geminated in spring & $2.67 \pm 0.35^{\mathrm{b}}$ & $19.17 \pm 5.51^{\mathrm{b}}$ & $6.20 \pm 0.86^{\mathrm{b}}$ \\
秋季萌发小车前 Plantago minuta geminated in autumn & $11.51 \pm 0.86^{\mathrm{a}}$ & $287.50 \pm 30.34^{\mathrm{a}}$ & $23.07 \pm 1.31^{\mathrm{a}}$ \\
春季萌发尖喙 $\square$ 牛儿苗 Erodium oxyrrhynchum germinated in spring & $18.09 \pm 1.54^{\mathrm{b}}$ & $90.45 \pm 7.70^{\mathrm{b}}$ & $5.00 \pm 0.00^{\mathrm{a}}$ \\
秋季萌发尖喙 $\square$ 牛儿苗 Erodium oxyrrhynchum germinated in autumn & $97.00 \pm 4.36^{\mathrm{a}}$ & $485.00 \pm 21.79^{\mathrm{a}}$ & $5.00 \pm 0.00^{\mathrm{a}}$ \\
\hline
\end{tabular}

表中同一列中不同字母表示差异显著 $(p<0.05)$ Data following with different letters in the same column indicate significant difference $(p<0.05)$

表 2 两种春季萌发秋季萌发的短命植物的物候(日/月)

Table 2 Phenological date of the two ephemerals germinated in spring and autumn (Day/month)

\begin{tabular}{|c|c|c|c|c|}
\hline $\begin{array}{c}\text { 植物表现型 } \\
\text { Phenotypes }\end{array}$ & $\begin{array}{c}\text { 现蕾 } \\
\text { Bud stage }\end{array}$ & $\begin{array}{c}\text { 开花期 } \\
\text { Florescence }\end{array}$ & $\begin{array}{c}\text { 花果期 } \\
\text { Florescence and fructescence }\end{array}$ & $\begin{array}{c}\text { 干枯 } \\
\text { Withered }\end{array}$ \\
\hline 春季萌发小车前 Plantago minuta geminated in spring & $8 / 5$ & $14 / 5$ & $15 / 5 \sim 7 / 6$ & $7 / 6$ \\
\hline 秋季萌发小车前 Plantago minuta geminated in autumn & $21 / 4$ & $26 / 4$ & $7 / 5 \sim 3 / 6$ & $3 / 6$ \\
\hline 春季萌发尖喙口牛儿苗 Erodium oxyrrhynchum germinated in spring & $5 / 5$ & $19 / 5$ & $20 / 5 \sim 5 / 6$ & $5 / 6$ \\
\hline 秋季萌发尖喙 $\square$ 牛儿苗 Erodium oxyrrhynchum germinated in autumn & $29 / 4$ & $5 / 5$ & $16 / 5 \sim 2 / 6$ & $2 / 6$ \\
\hline
\end{tabular}

如图 3 所示, 各个时期秋季萌发的小车前和尖 鲒 $\square$ 牛儿苗根系的菌根侵染率均高于同期春季萌发 小车前的和尖喙 $\square$ 牛儿苗的，二者区别在于小车前 菌根侵染率随着植株的生长而不断增加，而尖喙 $\square$ 牛儿苗的菌根侵染率在植株进入生殖生长期以后基 本维持在原来水平, 甚至有所下降。

\section{4 植株冠幅大小间差异}

植被盖度对减小地表风速、保持地表温度、降低 水分蒸发具有重要的意义，在植株个体数量一定的 情况下植株的冠幅大小决定植被盖度大小。研究发 现:在各个时期秋季萌发的小车前和尖喙 $\square$ 牛儿苗 的单株冠幅均比同期的春季萌发的小车前和尖喙 $\square$ 牛儿苗的大(图 4)。两种表现型的小车前的冠幅变 化动态基本一致 均表现为增长速度比较缓慢、增长 幅度不大、趋势比较平缓;而秋季萌发的尖喙 $\square$ 牛儿 苗在 5 月上旬进入花期以后植株冠幅增长速度增加 迅速，而且秋季萌发的尖喙 $\square$ 牛儿苗的冠幅多在 $50 \sim 60 \mathrm{~cm}$,大的可以达到 $80 \mathrm{~cm}$, 远远大于春季萌发 的尖喙口牛儿苗的冠幅(多在 $20 \mathrm{~cm}$ 左右, 大的也就 $30 \mathrm{~cm}$ )。

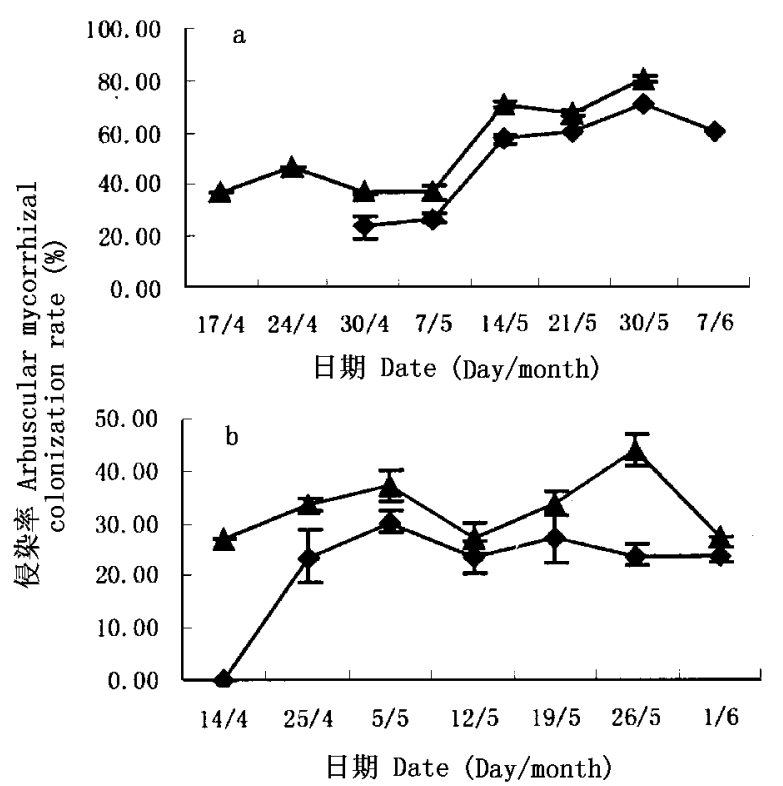

图 3 春季萌发的和秋季萌发的小车前 (a)和尖喙 $\square$ 牛儿苗 (b) 根系的丛枝菌根真菌侵染状况

Fig. 3 Mean arbuscular mycorrhizal colonization rate of Plantago minuta (a) and Erodium oxyrrhynchum (b) germinated in spring and autumn 图注见图 1 Notes see Fig. 1 



日期 Date (Day/month)

图 4 春季萌发的和秋季萌发的小车前 (a)和尖喙 $\square$ 牛儿苗 (b) 冠幅变化动态

Fig. 4 The crown of Plantago minuta (a) and Erodium oxyrrhynchum (b) germinated in spring and autumn 图注见图 1 Notes see Fig. 1

\section{3 讨 论}

古尔班通古特沙漠环境恶劣、养分贫瘦、降水稀 少, 对多数植物的生长发育不利, 然而短命植物却能 在这种恶劣的条件下生长的很好并形成明显的层 片, 说明短命植物必然具有高效利用土壤养分、水分 和光照资源的生理生态机制，以适应极端环境。Shi 等(2006a，2006b) 报道,古尔班通古特沙漠地区 $89 \%$ 的短命植物可以形成丛枝菌根，与丛枝菌根共 生是这类植物的一个重要适应策略。在室内培养条 件下，丛枝菌根真菌能够显著改善小车前和尖喙 $\square$ 牛儿苗的营养状况, 促进它们的生长 ${ }^{1}$ (石兆勇, 2006)。本研究发现秋季萌发的小车前和尖喙 $\square$ 牛 儿苗的根系侵染率高于春季萌发的小车前和尖喙 $\square$ 牛儿苗, 说明丛枝菌根真菌对于春、秋萌发的两种表 现型适应土壤贫㾑的能力和对养分的竞争能力具有 帮助。秋季萌发的小车前和尖喙 $\square$ 牛儿苗与菌根真 菌共生时间长, 尤其是在早春返青以后原来共生在 根系上的菌根真菌也能够在早春开始随着根系的继
续生长而不断侵染新生根系, 因此它们的菌根侵染 率也必然高于春季萌发的植物。同时, 这一结果也 表明，丛枝菌根真菌对秋季萌发的短命植物生长的 贡献更大。

种子是植物种群繁衍后代延续的基础, 是植物 保持种群的稳定性、进行散布和度过不良环境条件 的主要载体 (马绍宾等, 2001)。种子数量对于大多 数靠种子进行种群繁衍的一年生短命植物的种群发 展具有决定性的意义(Primack，1979)。干旱是荒漠 地区植物生长的重要限制因子, 特别是古尔班通古 特沙漠 6 月初干旱来临之际正值大多数短命植物的 生殖生长时期, 快速完成生长发育并顺利地躲避干 旱是短命植物的一个重要生存策略 (张立运, 2002a , 2002b)。本研究发现秋季萌发的小车前和尖 喙 $\square$ 牛儿苗生殖生长的时期比春季萌发的小车前和 尖喙 $\square$ 牛儿苗提早 $1 \sim 2$ 周, 这为秋季萌发的植株顺 利完成生活史提供了保障。

Klinkhamer 等(1997)报道，一次性结实植物的种 子产量与植株个体大小呈正相关, 植株个体越大种 子产量越高。研究发现秋季萌发的小车前和尖喙 $\square$ 牛儿苗植株个体生物量远远大于春季萌发的, 并且 秋季萌发的植株单株种子数量比春季萌发的高几倍 到十几倍。秋季萌发的小车前和尖喙 $\square$ 牛儿苗生产 的大量种子丰富了地下种子库, 为其后代种群的稳 定繁衍提供了保证。从个体水平来看, 秋季萌发的 小车前和尖喙 $\square$ 牛儿苗对地下种子库容量的贡献远 大于春季萌发的。从我们的调查来看, 样地内春季 萌发的小车前和尖喙 $\square$ 牛儿苗的数量大于秋季萌发 的, 但是由于短命植物的分布的空间变异性很大(张 涛等, 2006)，因此本研究无法在群落水平上对两种 表现型的植株对种子库贡献大小进行定量评价。

在荒漠生态系统中, 植被盖度的增加能够有效 地降低风速、减轻土壤风蚀、提高土壤保水能力, 从 而减少地表土壤细微颗粒及养分的损失, 对稳定地 表、降低沙尘暴的发生具有重要的作用 (Skidmore \& Powers, 1982 ; 钱亦兵等，2004)。植被盖度对荒漠 生态环境的保护具有重要的意义, 在植物密度大小 有限时植株冠幅大小成为决定植被盖度大小的重要 因素,植株冠幅越大植被盖度越大 (Rittenhouse \& Sneva，1977)。本研究发现, 秋季萌发的小车前和尖

1) Chen ZC (陈志超) (2006). Study on Function Diversity and Their Mechanism of AMF Associated With Ephemeral Plants (短命植物丛枝菌根真菌功 能多样性及机理). Master degree dissertation, Xinjiang Institute of Ecology and Geography, Chinese Academy of Sciences , 19-25. (in Chinese with English abstract) 
喙 $\square$ 牛儿苗植株冠幅显著大于春季萌发的小车前和 尖喙口牛儿苗，从个体水平来看秋季萌发小车前和 尖喙 $\square$ 牛儿苗的防风固沙能力大于春季萌发的小车 前和尖喙 $\square$ 牛儿苗。虽然秋季萌发的小车前和尖喙 $\square$ 牛儿苗在数量上不及春季萌发小车前和尖喙 $\square$ 牛 儿苗,但是由于植株冠幅较大, 因此对于提高该地区 植被盖度、提高水土保持能力和防风固沙能力仍具 有重要的意义。

综上所述，本项研究揭示了古尔班通古特沙漠 南缘白梭梭 (Haloxylon persicum) 群落中的短命植物 层片存在着秋季萌发和春季萌发两种表现型, 这两 种表现型的生态生物学特性存在显著的差异。目前 的研究对于春季萌发短命植物关注较多, 而对于秋 季萌发的短命植物在短命植物层片中的密度、种子 繁殖量、个体竞争能力和防风固沙能力, 以及丛枝菌 根真菌对其生长发育的作用等方面都缺乏深入系统 的研究。在较大尺度上阐明春季和秋季萌发的短命 植物种类、种子萌发的条件、以及它们对于古尔班通 古特沙漠生态系统的稳定的贡献等也是值得深入研 究的问题。

\section{参 考 文 献}

Biemann B, Linderman RG (1981). Quantifying vesicular arbuscular mycorrhizae: a proposed method towards standardization. New Phytologist, 87, 63-67.

Briget RS, Robert CR, David AS, David EP, Kevin FD (2005). Impact of land use and land cover change on groundwater recharge and quality in the southwestern US. Global Change Biology, 11, $1577-1593$.

Breitmeyer CM, Martow TA (1998). Resource availability and population size in cactophilic Drosophila. Functional Ecology, 12, $14-21$

Gutterman Y (2000). Environmental factors and survival strategies of annual plants in the Negev Desert, Israel. Plant Species Biology, $15,113-125$.

Klinkhamer PGL, de Jong TG, Meth H (1997). Sex and size in cosexual plants. Trends in Ecology and Evolution, 12, $260-$ 265 .

Lü L (吕玲), Tan DY (谭敦炎) (2005). The characteristics of fruit-set and reproductive package in four species of ephemeral plants in Eremopyrum (Poaceae). Journal of Xinjiang Agricultural University (新疆农业大学学报), 28(3), 21-25. (in Chinese with English abstract)

Mao ZM (毛祖美), Zhang DM (张佃民)（1994）. The conspectus of ephemeral flora in Northern Xinjiang. Arid Zone Research (干旱区研究) , 11(3), 1-26. (in Chinese with English abstract)

Margaret FM, Gilles H (2000). Why are annual plants rarely spring ephemerals? New Phytologist, 148, 295 - 302 .

Ma SB (马绍宾), Jiang HQ (姜汉侨), Huang HY (黄衡宇)

(2001) . A primary study on seed production of medicinal plant Sinopodophyllum hexandrum. Journal of Applied Ecology (应用 生态学报), 12, 363 - 368. (in Chinese with English abstract) Pan WB (潘伟斌), Huang PY (黄培 $\square$ ) (1995). The ecology of four ephemeral plants. Acta Phytoecology Sicina (植物生态学 报), 10, 85-91. (in Chinese with English abstract)

Primack RB (1979). Reproductive efforts in annual and perennial sprees of Plantago. American Naturalist, 114, 51-62.

Qian YB (钱亦兵), Wu ZN (吴兆宁), Zhang LY (张立运), Shi QD (师庆东), Wang XY (汪溪远) (2004). Ground-surface conditions resulting in dust storms in the south Junggar Basin. Arid Land Geography (干旱区地理), 27, 540-542. (in Chinese with English abstract)

Rittenhouse LR, Sneva FA (1977). A technique for estimating big sagebrush production. Journal of Range Management, 30, 68 74 .

Shi ZY, Feng G, Christie P, Li XL (2006a). Arbuscular mycorrhizal status of spring ephemerals in the desert ecosystem of Junggar Basin, China. Mycorrhiza, 16, 269-275.

Shi ZY, Zhang LY, Feng G, Christie P, Tian CY, Li XL (2006b). Diversity of arbuscular mycorrhizal fungi associated with desert ephemerals growing under and beyond the canopies of Tamarisk shrubs. Chinese Science Bulletin, 51 (Suppl. I ), $132-139$.

Shi ZY (石兆勇) (2006). Biodiversity and Ecological Function of Arbuscular Mycorrhizal Fungi Associated With Spring Ephemerals in the North of Xinjiang (早春荒漠短命植物的共生 AM 真菌生 物多样性及其生态效应研究). $\mathrm{PhD}$ dissertation, China Agricultural University, Beijing, 56-67. (in Chinese with English abstract)

Skidmore EL, Powers DH (1982). Dry soil-aggregate stability: energy-based index. Soil Science Society of America Journal, 46, $1274-1278$.

Trouvelot A, Kough JL, Gianinazzi-Pearson V (1986) . Measure du taux de mycorrhization VA d'un systeme radicularie. recherché de methods d' estimation ayant une signification funvtionnelle. In: Gianinazzi-Pearson V, Gianinazzi S eds. Physiological and Genetic Aspects of Mycorrhizae. INRA Press, Paris, 217-221.

Wan MW (宛敏渭), Liu XZ (刘秀珍) (1979). The Observation Methods of Phenology in China (中国物候观测方法). Science Press, Beijing. (in Chinese)

Wang XQ (王雪芹), Jiang J (蒋进), Lei JQ (雷加强), Zhang WM (张伟民), Qian YB (钱亦兵) (2003). The distribution of ephemeral vegetation on the longitudinal dune surface and its stabilization significance in the Gurbantunggut Desert. Acta Georgraphica Sinica (地理学报), 58, 598-605. (in Chinese with English abstract)

Wang XQ, Jiang J, Wang YC, Luo WL, Song CW, Chen JJ (2006) . Responses of ephemeral plant germination and growth to 
water and heat conditions in the southern part of Gurbantunggut Desert. Chinese Science Bulletin, 51 (Suppl. I ), 110-116.

Wu L (吴玲), Ren X (任霞), Wang SM (王绍明) (2005a). Study on germination of Eremurus inderiensis. Seed (种子), 24 (7), $1-4$. (in Chinese with English abstract)

Yao H (姚红), Tan DY (谭敦炎) (2005a). The growth characteristics and the reproductive allocation dynamics in four ephemeral species of Trigonella. Journal of Xinjiang Agricultural University (新疆农业大学学报), 28(3), 26-29. (in Chinese with English abstract)

Yao H (姚红), Tan DY (谭敦炎) (2005b). Size dependent reproductive output and life-history strategies in four ephemeral plants of Tigonella. Acta Phytoecologica Sinica (植物生态学 报), 29, 954 - 960. (in Chinese with English abstract)

Ye WY (叶卫英), Yin LK (尹林克), Qian Y (钱翌), Yan C
(严成) (2005). Study on the vegetation type of Yamalike Mountain and plant diversity characteristic. Environmental Protection of Xinjiang (新疆环境保护), 27(2), 1-4. (in Chinese with English abstract)

Zhang LY (张立运) (2002a). The ephemeral plants in Xingjiang ( I ) : special eco-biological characteristics. Plants (植物杂 志), (1), 4-6. (in Chinese)

Zhang LY (张立运) (2002b). The ephemeral plants in Xingjiang ( III ) : significance in coenology and resource value. Plants (植 物杂志), (3), 4-5. (in Chinese)

Zhang T (张涛), Tian CY (田长彦), Sun Y (孙羽), Feng G (冯固) (2006). Soil seed banks of ephemerals in the Gurbantunggut Desert Area. Arid Land Geography (干旱区地理), 29, 675 - 681. (in Chinese with English abstract) 